\title{
Ultrastructure of marine snow. II. Microbiological considerations
}

\author{
Andreas Heissenberger ${ }^{1}$, Gary G. Leppard ${ }^{2}$, Gerhard J. Herndl ${ }^{1, *}$ \\ ${ }^{1}$ Institute of Zoology, University of Vienna, Althanstr. 14, A-1090 Vienna, Austria \\ ${ }^{2}$ Aquatic Ecosystem Protection Branch, National Water Research Institute, Environment Canada, Burlington, Ontario, \\ Canada L7R 4A6; and Department of Biology, McMaster University, Hamilton, Ontario, Canada L8S 4K1
}

\begin{abstract}
Marine snow from the northern Adriatic Sea was examined using transmission electron microscopy (TEM) and non-disturbing embedding techniques in combination with ultrathin sectioning to visualize the fibrillar matrix of the snow and of the associated microorganisms at a resolution of ca $1 \mathrm{~nm}$. Despite the high degree of heterogeneity of marine snow, TEM images clearly show fibrilmediated associations between algae, bacteria and embedded organic and inorganic particles. The similarity in morphology between diatom-derived polysaccharides and the dominant fibrils in the marine snow matrix led us to suggest that diatoms (mainly Chaetoceros sp.) were the most important producers of mucilage in the northern Adriatic Sea in summer 1993. Bacteria, however, also produced copious amounts of fibrillar material in marine snow, influencing the structure and probably the physical properties of the predominantly algae-derived matrix. While $42 \%$ of the marine-snow-associated bacteria exhibited a capsular envelope larger than their respective cell diameters and only $5 \%$ were lacking a capsule, only $12 \%$ of free-living bacteria exhibited a fully developed capsule and $37 \%$ were lacking any visible capsule. Thus we conclude that given the high bacterial abundance in marine snow found in earlier studies, the capsular envelope of marine-snow-attached bacteria might significantly influence the physical and chemical structure of the overall polymeric matrix of marine snow.
\end{abstract}

KEY WORDS: Marine snow - Transmission electron microscopy $\cdot$ Mucus $\cdot$ Bacterial capsules $\cdot$ Colloids Adriatic Sea

\section{INTRODUCTION}

Marine snow has received considerable attention as a vehicle to rapidly transfer carbon from the euphotic zone to deeper layers of the ocean. Despite its ubiquitous occurrence in the world's oceans, marine snow formation occasionally leads to excessive amounts of mucilaginous material in the water column, such as in the northern Adriatic Sea (Herndl \& Peduzzi 1988, Herndl 1992). In this semi-enclosed sea, a peculiar current system brings oligotrophic Mediterranean waters along the Croatian coast to the shallow northern Adriatic and along the Italian coast back to the Mediterranean Sea: this current system is modified

- Addressee for correspondence.

E-mall: gerhard.herndl@univie.ac.at occasionally during summer when the northern Adriatic becomes more or less isolated from the remaining parts of the Adriatic Sea (Orlic 1987). Under such conditions, the water column of the northern Adriatic is highly stratified, and thus low-turbulence conditions prevail. Recently, it has been suggested that the combination of this isolation of the northern Adriatic Sea due to the modification of the current system, a well developed pycnocline and a low-turbulence regime are prerequisites for the development of large masses of mucilage (Müller-Niklas et al. 1994). Despite these physical preconditions, a major factor leading to excessive marine snow formation is an imbalance in the supply of inorganic nutrients, loading, in tum, to an 'overflow reaction' in phytoplankton primary production (Fogg 1990). In 1991, a massive occurrence of marine snow in the northern Adriatic Sea was accompanied 
by a high N:P ratio of inorganic nutrients of $\sim 70$ and a photosynthetic extracellular release (PER) of $\sim 80 \%$ (Kaltenböck \& Herndl 1992) in the surrounding water, while marine-snow-associated phytoplankton exhibited a significantly lower PER under more balanced nutrient conditions. Similarly, Myklestad \& Haug (1972) and Fogg (1990) found in laboratory studies that phosphorus-depleted primary production is responsible for high PER rates. Phosphorus-depleted primary production, however, is a specific characteristic of the northern Adriatic Sea, making it especially susceptible to excessive marine snow formation. Morcover, Obernosterer \& Herndl (1995) recently showed that, under phosphorus-depleted conditions, high PER accumulates in the system and is not taken up by bacterioplankton since, in turn, their growth is phosphoruslimited as well.

Although a series of studies has been performed on the role of microorganisms in the formation and degradation of marine snow and in its chemical composition (reviewed in Alldredge \& Silver 1988), the structure of the fibrillar matrix remains largely unknown. Applying Alcian blue as a carbohydrate-selective stain and optical microscopy (Kiørboe \& Hansen 1993, Passow \& Alldredge 1995, Schuster \& Herndl 1995), it has been shown that micrometer-sized 'transparent exopolymer particles' are abundant in surface waters (up to $10^{3} \mathrm{ml}^{-1}$ ). Due to their polysaccharidic origin and their stickiness, these small particles might function as precursors of marine snow. Ultrastructural examinations using high resolution transmission electron microscopy (TEM) can reveal further information on these transparent exopolymer particles, the formation of marine snow, the interactions of microorganisms within the particles and the role of microorganisms in the alteration of the mucilage. As marine snow is greatly enriched not only with phytoplankton cells but also with bacteria (Müller-Niklas et al. 1994) as compared to the ambient water, a major influence of these organisms should be detectable on the physical and chemical properties of the mucilaginous matrix.

Recently, Tranvik (1993) and Heissenberger \& Herndl (1994) showed that bacteria release high molecular weight substances into the surrounding water. These organic macromolecules have been shown to be rather refractory. Therefore, bacterial activity associated with marine snow might change the matrix of marine snow in 2 ways. On the one hand, the macromolecules within fibrils may be cleaved due to bacterial ectoenzymatic activity, with the resulting mono- and oligomers being taken up by bacteria (Karner \& Herndl 1992, Smith et al. 1992). On the other hand, it has been shown that the availability of surfaces stimulates the production of exopolysaccharides by bacteria (Vandevivere \& Kirchman 1993) and that the production of polysaccharidic fibrillar capsules is an important mechanism for attachment (Corpe 1970, Fletcher \& Floodgate 1973, Costerton 1984). These findings, and the assumption that particles trapped in marine snow provide a substrate for bacterial attachment, suggest that the production and release of refractory organic matter by marine-snow-associated bacteria may contribute to the formation of the fibrillar matrix and the gluing together of particles, ultimately resulting in the formation of larger aggregates (Leppard 1995).

The aim of this study is to elucidate the uitrastructure and natural associations of the marine-snow-associated microorganisms using a newly developed technology (Leppard et al. 1996, this issue) to minimize perturbation of the highly hydrated polysaccharide fibrils (see Leppard et al 1996 for an in-depth description of the methods). Furthermore, specific attention was paid to characterization of the envelope of capsular material of free-living and marine-snow-associated bacteria.

\section{MATERIAL AND METHODS}

Study site and sampling. Marine snow and ambient water samples were collected along a trophic gradient across the northern Adriatic Sea in July 1993 (for a detailed description of the sampling stations see Karner et al. 1992) as well as in nearshore waters off Rovinj (Croatia). Samples were taken from various depth layers with rinsed Niskin bottles as well as by SCUBA divers with hand-made syringes as described in Herndl \& Peduzzi (1988). From on board the RV 'Vila Velebita', marine snow from each respective sampling depth was collected as described in detail in Leppard et al. (1996)

Optical microscopy. In order to obtain an overview of the matrix of marine snow, 1 or 2 aggregates with ambient water were stained with a few drops of a toluidine-blue solution $10.02 \%$ in distilled water on a microscope slide, thoroughly mixed during application). After $20 \mathrm{~min}$, the stained particles were covered with a cover slide and observed under a Nikon (Microphot-SA) optical microscope.

Transmission electron microscopy. As outlined in detail in the companion paper (Leppard et al. 1996), 4 different preparatory treatments were used correlatively; this allowed us to delineate the specific artifacts inherent in each of the preparatory treatments. All preparations were performed in 5 replicates and within 10 min after sampling in order to avoid storage artifacts (Perret et al. 1991, Leppard 1992). Ultrathin sections of embedded samples (50 to $70 \mathrm{~nm}$ ) mounted on grids were examined with a JEOL 1200 EX II TEMSCAN scanning-transmission electron microscope (STEM) operating at $80 \mathrm{keV}$ in transmission mode. 
Determination of the capsular envelope of bacteria. In order to determine the extent of the capsular envelope in bacteria, at least 3 sections of each replicate (ambient water and marine snow, respectively) were examined. In marine snow samples, only bacteria not directly embedded in the dense matrix of the flocs were considered (1) to ensure that the capsule is actually derived from the bacterium and (2) to allow a crude sizing of the capsular envelope. The size of the capsule was split in 4 categories: fully developed capsules covered the whole cell surface and were $\geq 1$ cell diameter; well-developed capsules were $>0.5$ to $\leq 1$ cell diameter or covered more than haif of the cell surface; poorly developed capsules consisted of only a few fibrils and/or covered less than half of the cell surface; cells lacking any capsule were also counted. In order to avoid underestimation of the size of the capsular envelope due to extraction artifacts, only glutaraldehyde/rutheniumred-fixed samples (Leppard et al. 1996) were examined.

\section{RESULTS}

Due to the heterogeneity and the large number of samples investigated, the comments below refer to the most common types of marine snow. During the investigation period, the marine snow was generally rather small, ranging from 0.5 to $20 \mathrm{~mm}$ in diameter.

\section{Optical microscopy}

Optical microscopy showed the heterogeneous structure of marine snow particles. As revealed by acidic polysaccharide-selective stains like toluidine blue, the main components of the matrix consisted of amorphous mucilaginous material (Fig. 1). Besides mucilage, the particles contained large numbers of diatoms (mainly Chaetoceros sp.), bacteria, organic debris (such as algal scales, fragments of bacterial cell walls and parts of zooplankton), and inorganics (such as fragments of diatom frustules or clay particles).

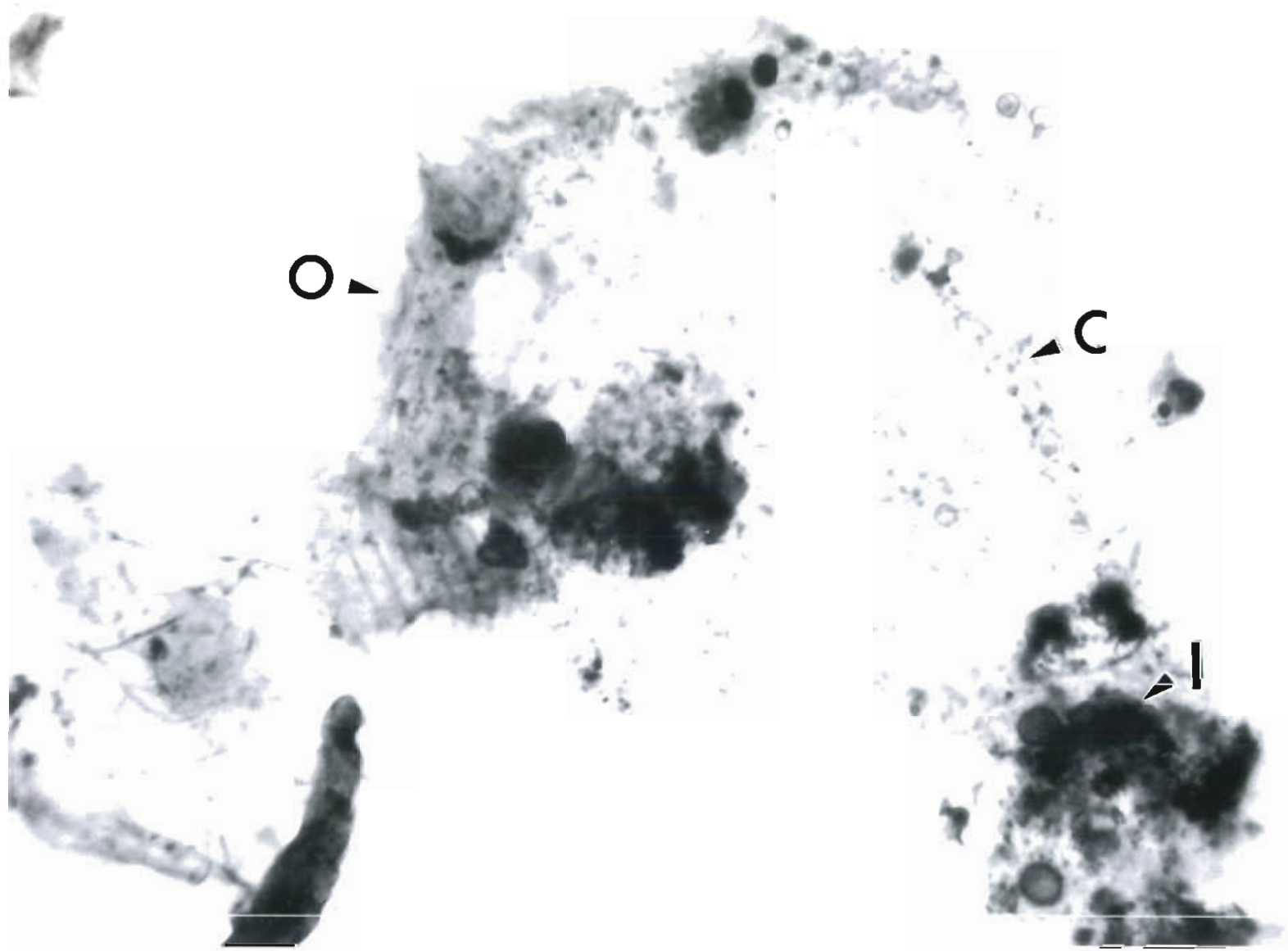

Fig. 1 Typical marine snow particle stained with toluidine blue and observed by optical microscopy; the amorphous mucilaginous matrix stains pink. Embedded in the matrix are Chaetoceros sp. cells (C), organic debris (O) and inorganic particles (I) 


\section{Ultrastructure of marine snow}

Despite the heterogeneity of marine snow, the large number of samples examined allowed us to make generalizations about the marine snow of the northern Adriatic Sea.

The general features detectable were: (1) bacteria were dominant in terms of numbers; (2) diatoms were the dominant eukaryotes; (3) polysaccharide fibrils were the major component of the mucilaginous matrix, providing a structural framework of polymer bridges which cross-connected other marine snow subcomponents (both colloids and true particles); (4) fibrils appeared to be mainly of algal origin, but a significant part of the matrix was bacteria-derived; (5) several mineral types were present in large marine snow; (6) no correlation was found between the trophic state of the water and general aspects of the ultrastructure of marine snow.

Besides fibrils and organisms, colloidal organic debris and organo-mineral debris were important components of the matrix of marine snow. Much of this debris consisted of submicron particles with distinctive geometry and substructure. Among these distinctive colloids were algal scales, coccoliths, patterned remains of bacterial cell walls, organic crystals, patterned tubes (possibly stalks from attached protozoans) and trichocysts.

Although 4 different preparation/embedding techniques were used, all samples illustrated here (except Fig. 1) were prepared using the glutaraldehyde + ruthenium red preparation because it yields the clearest images of the associations within the marine snow matrix (Leppard et al. 1996). The complexity of the structure of marine snow and the patchy distribution of bacteria and fibrils on the ultrastructural level are demonstrated in Fig. 2. Despite the extreme heterogeneity, subcomponents seemed to be connected and associated with each other. The most frequent microbe-microbe associations were bacterium-bacterium and bacterium-alga, with the alga being usually a colonial diatom (mostly Chaetoceros sp.). While the bacteria tended to be present as individual cells in mixed communities (Fig. 2A), discrete colonial types were also seen (Fig. 2B). Virus-virus and virus-bacterium associations were also detected.

Fig. 3 demonstrates the relationship between Chaetoceros sp. cells and their external mucilage. The alga was typically found as a small linear colony, with a small number of thin long setae projecting from each cell (Fig. 3A inset). A voluminous and irregular layer of mucilage surrounded the colony, with dense patches of mucilage attached to some setae. At high resolution, the gel-like structure of the mucilage was detectable as a 3-dimensional network of fibrils with a high porosity throughout much of the mucilage layer (Fig. 3A). Fig 3B shows the fibrils acting as polymer bridges with an average width of $\sim 5 \mathrm{~nm}$ and thus not detectable as individual fibrils by optical microscopy or conventional scanning electron microscopy. The fibrils in Fig. 3B are part of a dense patch of mucilage which cross-connects several setae. Many Chaetoceros sp. cells found in marine snow were not active, either being devoid of cytoplasm or containing spores.

Fig. 4 represents a selection of marine-snowassociated bacteria surrounded by capsular envelopes. The fibrillar component is well developed in each case. It is evident from Fig. 4 that the structure of fibrils can be different in different bacteria and that more than 1 fibril morphotype can be found per bacterium. Generally, marine-snow-associated bacteria were found to have their capsular envelope more extensively developed than free-living bacteria (Table 1, Fig. 5). While $42 \%$ of the marine-snowassociated bacteria exhibited a capsular envelope larger than their cell diameter, the corresponding value for free-living bacteria was only $12 \%$. On the other hand, $37 \%$ of the free-living bacteria but only $5 \%$ of marine-snow-associated bacteria had no capsule (Table 1).

\section{DISCUSSION}

Under the special nutrient conditions of the northern Adriatic Sea it has been previously shown that photosynthetic extracellular release (PER) can reach $\sim 80 \%$ (Kaltenböck \& Herndl 1992) and leads subsequently to the formation of marine snow. Using TEM, this commonly assumed 'dissolved' PER has been shown to consist at least partially of polysaccharide fibrils linked closely together, providing an efficient 'trap' for bacteria and other small particles (see also Kepkay et al. 1993).

In the northern Adriatic Sea, marine snow has been shown to become increasingly enriched with bacteria over a period of $\sim 3$ mo (Müller-Niklas et al. 1994). Given the high abundance of marine-snow-attached bacteria and the high percentage of bacteria $(-70 \%)$ with a capsular envelope of at least half of the cell diameter (Table 1, Figs. $4 \& 5$ ), it is evident that marine-snow-associated bacteria might contribute substantially to the polysaccharide matrix of marine snow. Capsular envelopes similar to those shown in Figs. 4 \& 5 have also been documented by Cowen (1992). The production of these exopolysaccharides is stimulated by the presence of inorganic particles or organic debris, as demonstrated by Vandevivere \& Kirchman (1993). These authors suggest that most marine bacteria are able to adapt their ability to pro- 


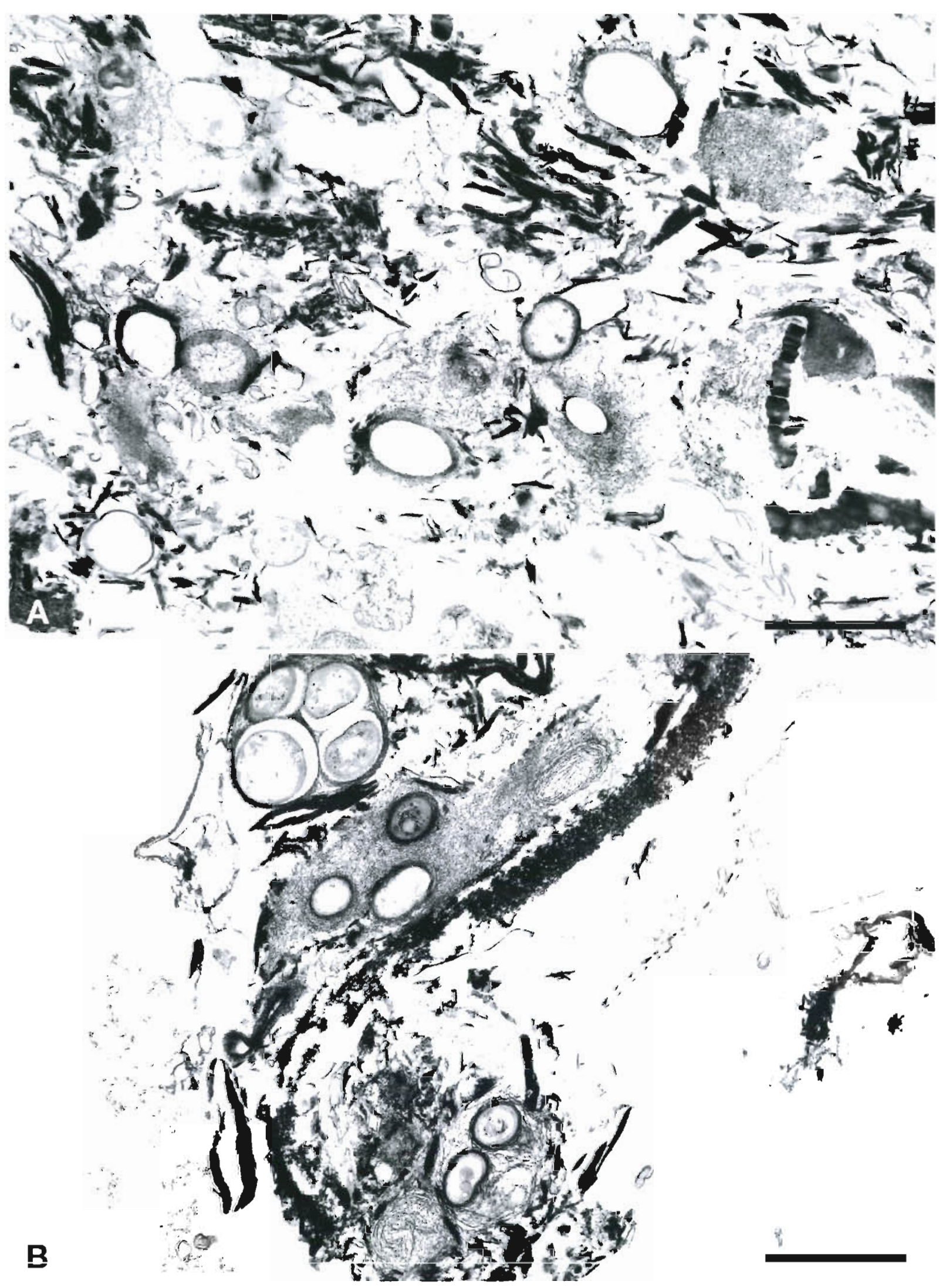

Fig. 2. TEM images of ultrathin sections of the interior of a large marine snow particle, lllustrating the complexity and the patchlness of individual compartments. (A) Bacteria dispersed as individual cells, (B) discrete bactenal microcolones Scale bar $=10 \mu \mathrm{m}$ 


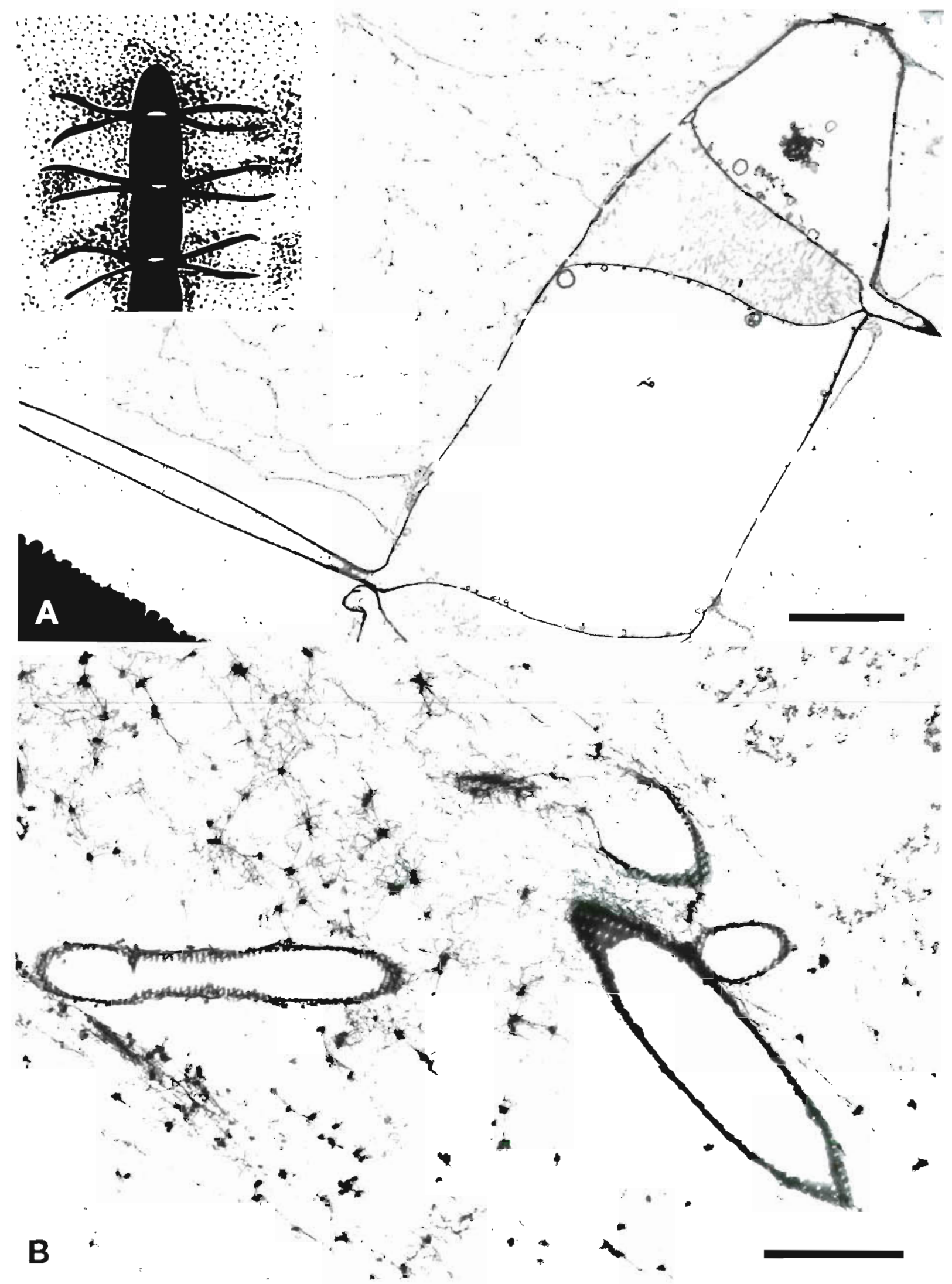

Fig. 3. TEM images of the most common type of marine snow. (A) Highly hydrated structures of the fibrillar network and mucilaginous material most likely extruded from a Chaetoceros sp. cell thand-drawn inset shows a Chaetoceros sp. cell in relation to external mucilage). (B) At greater magnification, dense and porous regions are revealed within a patch of fibrils, indicatıng the heterogeneity of the matrix. Scale bars: (A) $3.0 \mu m_{i}$ (B) $1.0 \mu \mathrm{m}$ 

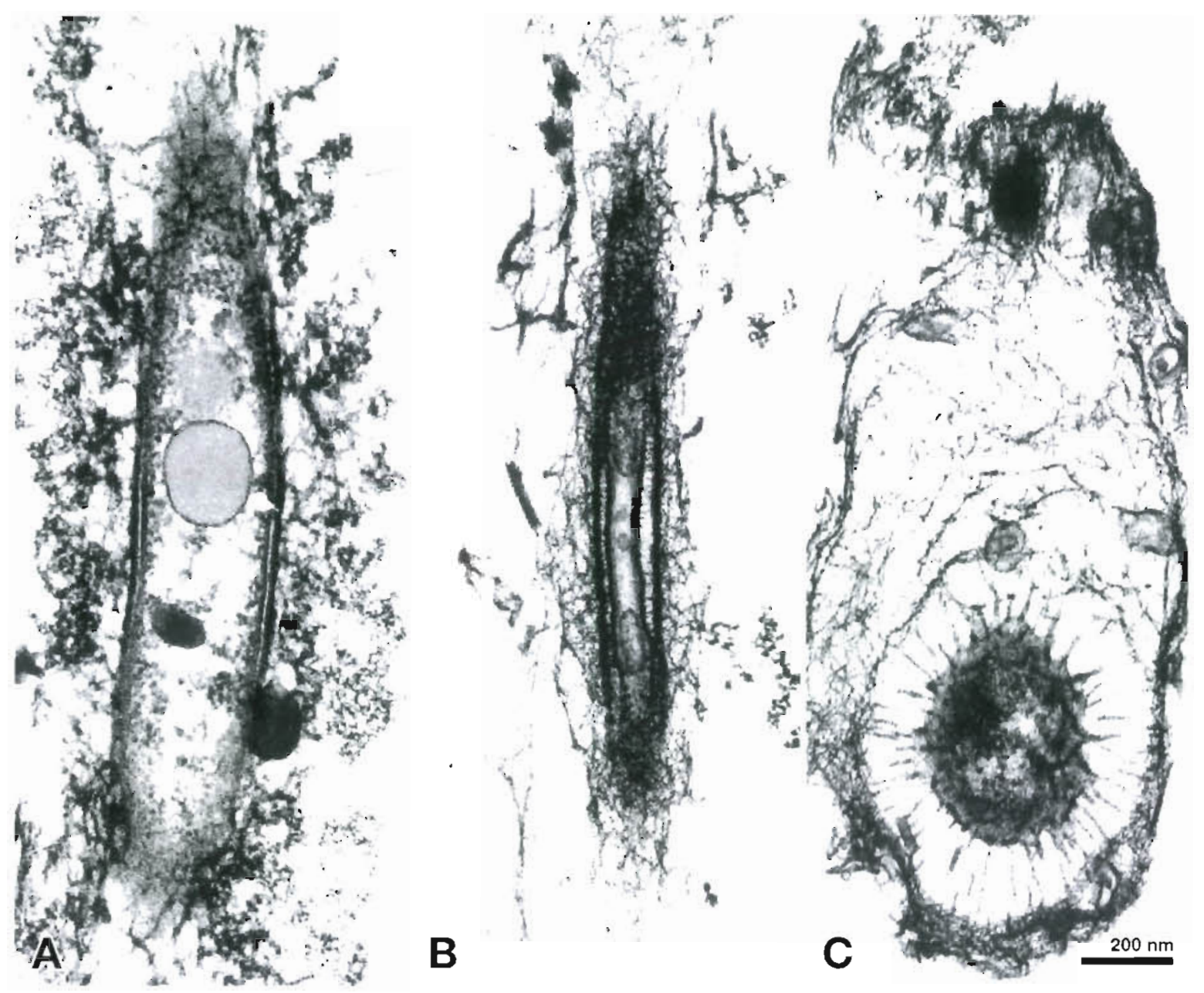

Fig. 4. TEM images of 3 different morphotypes of marıne snow-associated bacteria; these bacteria exhibit a well-developed fibrillar capsule exceeding the actual cell volume

duce exopolysaccharides depending on the availability of colonizable surfaces. Bacterial adhesion via polysaccharide production has also been shown to be induced by starvation (Wrangstadh et al. 1986) and to be a major mechanism in the attachment to surfaces (Fletcher \& Floodgate 1973, Costerton 1984). The large extension of the capsular envelope in marine-snowassociated bacteria might be interpreted as an anchor site for the bacterium on the surface and, additionally, as a site to scavenge charged molecules (amino acids, metals). There is evidence that marine-snow-associated bacteria exhibit higher ectoenzymatic activity per cell than do free-living bacteria (Karner \& Herndl 1992. Smith et al. 1992). Since it is thought that a large portion of the ectoenzymes is embedded in the capsular envelope (Chróst 1991), it is thought that the frequently detected higher per-cell activity is directly related to the dimension of the capsular envelope.

Table 1 Development of the capsular envelope in free-living versus marine-snow-associated bacteria (for a description of the criteria see 'Materials and methods'). Values are given as mean precentage $\pm \mathrm{SD}$ ( $\mathrm{n}=6$ for ambient water, $\mathrm{n}=5$ for marine snow). Total number of bacteria enumerated was 109 free-living and 187 marine-snow-associated bactena

\begin{tabular}{|lcccc|}
\hline Bacteria & Fully developed & Well developed & Poorly developed & No capsule \\
\hline Free-living & $11.88 \pm 6.24$ & $28.17 \pm 11.91$ & $23.20 \pm 9.26$ & $36.75 \pm 7.79$ \\
Marine-snow-associated & $42.12 \pm 10.42$ & $28.08 \pm 11.75$ & $24.68 \pm 5.46$ & $5.12 \pm 3.10$ \\
\hline
\end{tabular}



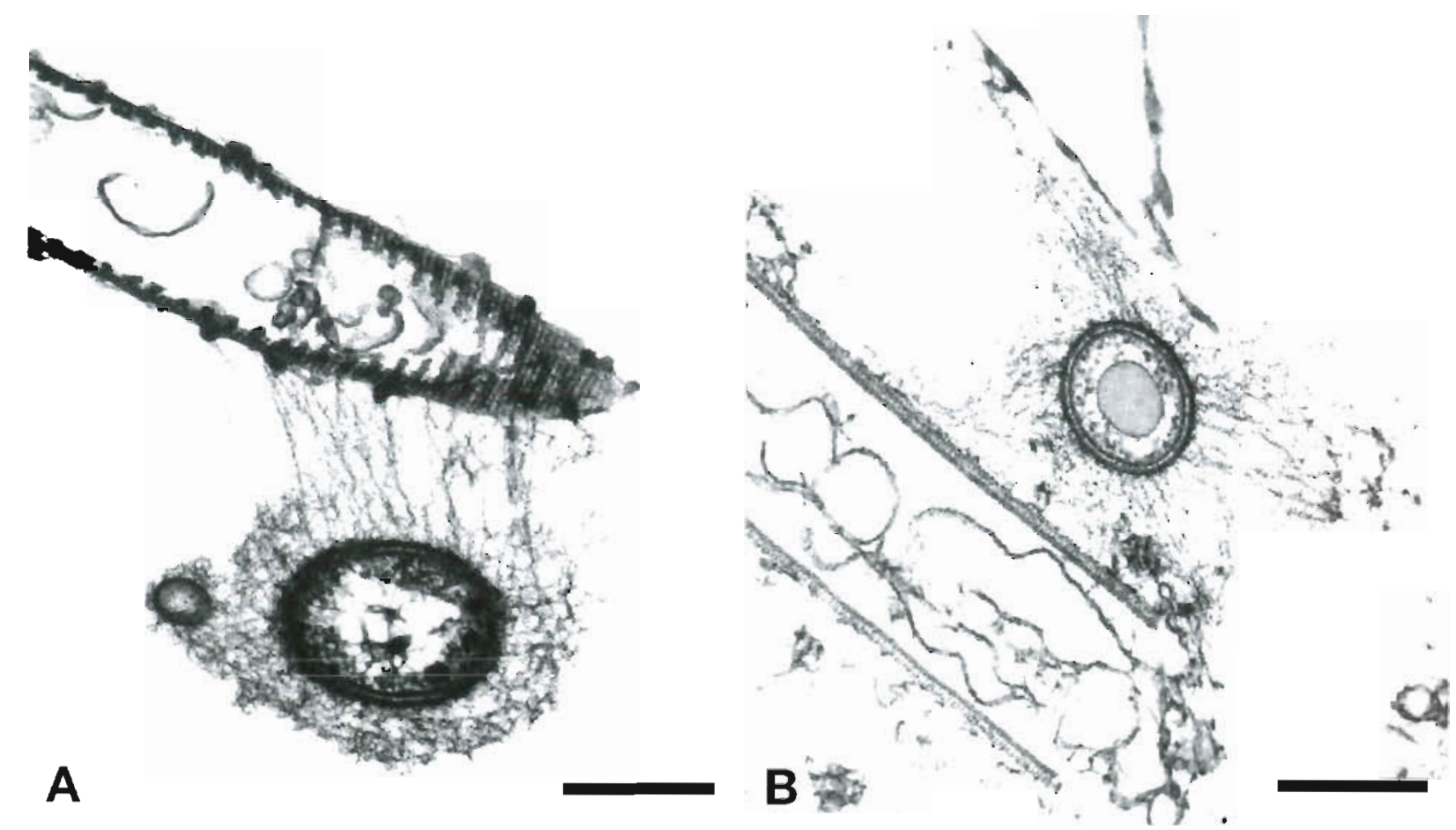

Fig. 5. TEM micrographs showing specific bacterial attachments. (A) A bacterium attached with fibrils to a diatom seta. (B) A bacterium attached to debris via polymer bridges of fibrils. Scale bar $=0.25 \mu \mathrm{m}$

A major biological contribution of this study rests in its description of the relationships between fibrils, fibril-secreting microorganisms, the mucilaginous matrix of marine snow and the various particulate and colloidal subcomponents of marine snow. These relationships are depicted in Fig. 6, which also indicates possible transformations between the various kinds of marine snow precursors and marine snow and their interaction with their physico-chemical environment. Some roles of important marine biota and molecules are shown in relation to marine snow and its fibrils. It is postulated in Fig. 6 that there is a size continuum from single polysaccharide fibrils (in the nm range), pro- duced and extruded across the cell surfaces of autoand heterotrophic microorganisms, to fibrillar mesh bundles or 'transparent exopolymer particles' (TEP) (in the $\mu \mathrm{m}$ range) or mucus sheets in the mm range. TEP are predominantly produced by turbulence and shear (Kiørboe 1993, Schuster \& Herndl 1995) and might, in turn, further aggregate to form eventually marine snow (size range: $\mathrm{cm}$ to $\mathrm{dm}$ ). Thus the entire spectrum of polysaccharide material ranges over $\sim 7$ orders of magnitude. All these polysaccharide-rich 'particles' outlined in Fig. 6 undergo modification due to aggregation, disaggregation, adsorption and desorption of a variety of molecules.

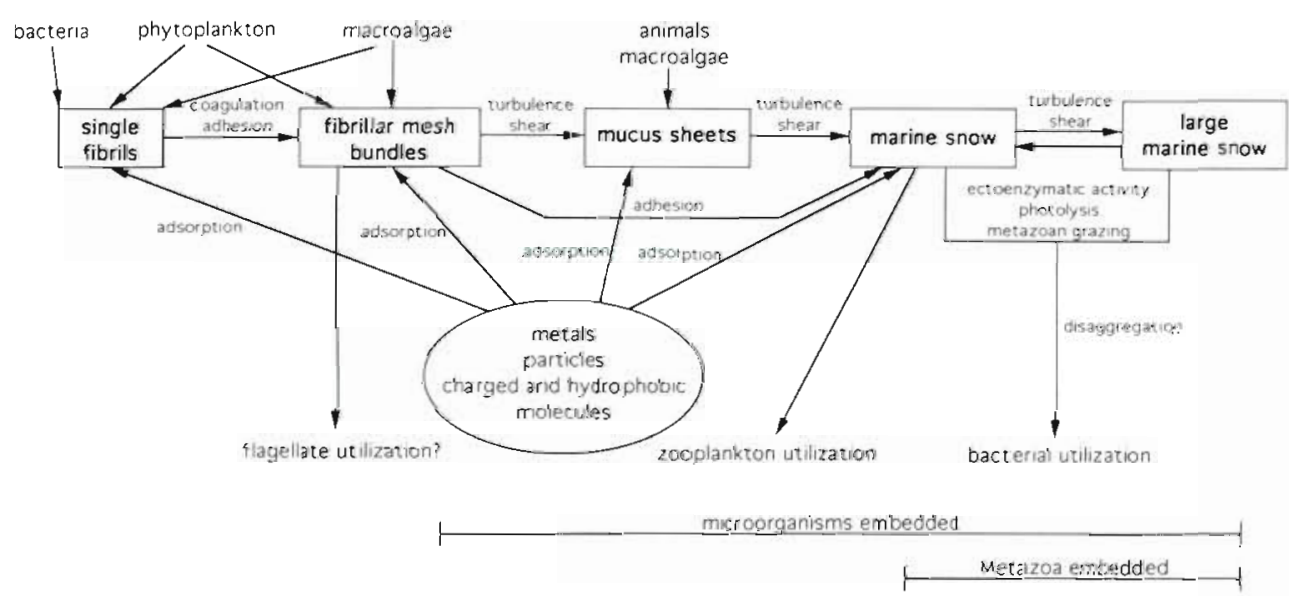

Fig. 6. Suggested scheme of polysaccharide particle formation in the sea. A size continuum is proposed from single fibrils (in the nm range) released by microorganisms to the large marine snow (in the dm range). At all levels of partucle size, these particles experience various physically, chemically and biologically mediated modifications 
In summary, we have shown that the careful use of TEM techniques provides insights into the microenvironment of bacteria and eukaryotes embedded in the fibrillar matrix of marine snow. Furthermore, we have demonstrated that bacterioplankton associated with marine snow produce copious amounts of capsular material which might act as a sorption site for molecules which are, in turn, taken up subsequently and/or act as a retention mechanism for ectoenzymes. We have presented evidence that the capsular envelope exceeds the volume of the cell in about $70 \%$ of the marine-snow-associated bacteria and in about $40 \%$ of the free-living bacteria. It is likely that this polysaccharide capsule has to be continuously renewed. The fate of the replaced polysaccharides remains unknown. This capsular material could either be released into the bulk seawater or degraded within the newly formed fibrillar matrix. Currently, experiments are being designed to answer these questions.

Acknowledgements. We are grateful to the staff of the Center for Marine Research (Rovin), Croatia), particularly to the captain and crew of the RV 'Vila Velebita' for their hospitality and help during sampling and to S. Puskaric for the use of his microscope. We want to thank M. Agis and G. Müller-Niklas (University of Vienna) for diving assistance, M. M. West, D. T Flannigan and J. Carson (McMaster University) for electron microscope services and J. N. A. Lott (McMaster University) for providing electron microscope facilities. Financial support was provided by the National Water Research Institute of Environment Canada to G.G.L. and by the Austrian Science Foundation (FWF grant 8608 and 9388) to G.J.H. A portion of this work was sponsored by the New Energy and Industrial Technology Development Organization (NEDO)/Research Institute of Innovative Technology for the Earth (RITE), both of Japan, to G.G.L. This work is in partial fulfillment of the requirements for a Ph.D. degree from the University of Vienna by A.H.

\section{LITERATURE CITED}

Alldredge AL, Silver MW (1988) Characteristics, dynamıcs and significance of marine snow. Prog Oceanogr 20:41-82

Chróst RJ (1991) Microbial enzymes in aquatic environments. Springer Verlag, New York

Corpe WA (1970) An acid polysaccharide produced by a primary film-forming marine bacterium. In: Developments in industrial microbiology. American Institute of Biological Sclences, Washington, DC, p 402-412

Costerton JW (1984) Direct ultrastructural examination of adherent bacterial populations in natural and pathogenic ecosystems. In: Klug MJ, Reddy CA (eds) Current perspectives in microbial ecology. American Society of Microbiology, Washington, DC, p 115-123

Cowen JP (1992) Morphological study of marine bacterial capsules: implications for marine aggregates. Mar Biol 114:85-95

Fletcher M, Floodgate GD (1973) An electron-microscopic demonstration of an acidic polysaccharide involved in the adhesion of a marne bacterium to solid surfaces. J Gen Microbiol 74:325-334
Fogg GE (1990) Massive phytoplankton gel production. In: Barth H, Fegan L (eds) Eutrophication-related phenomena in the Adriatic Sea and other Mediterranean Coastal zones. Water pollution research report 16 . Commission of the European Communities, Brussels, p 207-212

Heissenberger A, Herndl GJ (1994) Formation of high molecular weight material by free-living marine bacteria. Mar Ecol Prog Ser 111:129-135

Herndl GJ (1992) Marine snow in the northern Adriatic Sea: possible causes and consequences for a shallow ecosystem. Mar Microb Food Webs 6:149-172

Herndl GJ, Peduzzi P (1988) Ecology of amorphous aggregations (marine snow) in the Northern Adriatic Sea: I. General considerations. P.S.Z.N. I: Mar Ecol 9:79-90

Kaltenböck E, Herndl GJ (1992) Ecology of amorphous aggregations (manne snow) in the Northern Adriatic Sea: IV. Dissolved nutrents and the autotrophic community associated with marine snow. Mar Ecol Prog Ser 87:147-159

Karner M. Fuks D. Herndl GJ (1992) Bacterial activity along a trophic gradient. Microb Ecol 24:243-257

Karner M. Herndl GJ (1992) Extracellular enzymatic activity and secondary production in free-living and marine snow associated bacteria. Mar Biol 113:341-347

Kepkay PE, Niven SEH, Milligan TG (1993) Low molecular weight and colloidal DOC production during a phytoplankton bloom. Mar Ecol Prog Ser 100:233-244

Kiorboe T (1993) Turbulence, phytoplankton cell size, and the structure of pelagic food webs. Adv Mar Biol 29:1-72

Kiørboe T. Hansen JLS (1993) Phytoplankton aggregate formation: observations of patterns and mechanisms of cell sticking and the significance of exopolymeric material. J Plankton Res 15:993-1018

Leppard GG (1992) Evaluation of electron microscope techniques for the descruption of aquatic colloids. In: Buffle $J$, van Leeuwen HP (eds) Environmental particles, Vol. 1. Lewis Publishers, Boca Raton, p 231-289

Leppard GG (1995) The characterization of algal and microbial mucilages and their aggregates in aquatic ecosystems. Sci Total Environ 165:103-131

Leppard GG. Heissenberger A, Herndl GJ (1996) Ultrastructure of marine snow. I. Transmission electron microscopy methodology. Mar Ecol Prog Ser 135:289-298

Müller-Niklas G, Schuster S, Kaltenböck E, Herndl GJ (1994) Organic content and bacterial metabolism in amorphous aggregations of the northern Adriatic Sea. Limnol Oceanogr 39:58-68

Myklestad S, Haug A (1972) Production of carbohydrates by the marine diatom Chaetoceros affinis var. willei (Gran) Hustedt. I. Effect of the concentration of nutrients in the culture medium. J Exp Mar Biol Ecol 9:125-136

Obernosterer I, Herndl GJ (1995) Phytoplankton extracellular release and bacterial growth: dependence on inorganic N:P ratio. Mar Ecol Prog Ser 116:247-257

Orlic M (1987) Oscillations of the inertia period on the Adriatic Sea shelf. Cont Shelf Res 7:577-598

Passow U, Alldredge A (1995) Aggregation of a diatom bloom in a mesocosm: the role of transparent exopolymer particles (TEP). Deep Sea Res II 42:335-357

Perret D, Leppard GG, Müller M, Belzile N, DeVitre R, Buffle $J$ (1991) Electron microscopy of aquatic colloids: nonperturbing preparation of specimens in the field. Wat Res $25: 1333-1343$

Schuster SO. Herndl GJ (1995) Formation and significance of transparent exopolymeric particies in lile nurituen Adriatic Sea. Mar Ecol Prog Ser 124:227-236

Smith DC, Simon M, Alldredge AL, Azam F (1992) Intense hydrolytic enzyme actıvity on marine aggregates and 
implications for rapid particle dissolution. Nature 359 $139-142$

Tranvik LJ (1993) Microbial transformation of lablle dissolved organic matter into humic-like matter in seawater FEMS Microbiol Ecol 12:177-183

Vandevivere P, Kurchman OL (1993) Attachment stimulates

This article was submitted to the editor exopolysaccharide synthesis by a bacterium. Appl Environ Microbiol 59:3280-3286

Wrangstadh M, Conway PL, Kjelleberg S (1986) The production and release of an extracellular polysacchande during starvation of a marine Pseudomonas sp. and the effect thereof on adhesion. Arch Microbiol 145:220-227

Manuscript first received: July 6, 1995

Revised version accepted: December 11, 1995 